\title{
The Struggle of Jihadist's Ideology in Hikayah Wahabiyyah
}

\author{
Cahya Buana \\ Universitas Islam Negeri Syarif Hidayatullah Jakarta \\ email: cahya.buana@uinjkt.ac.id \\ Ahmadi Usman \\ Universitas Islam Negeri Syarif Hidayatullah Jakarta \\ email: ahmadi.usman@uinjkt.ac.id
}

\begin{abstract}
Hikayah Wahabiyyah was banned (2013) in Saudi Arabia because it was considered to undermine the honor of religion, institutions and state stability. Hikāyah Wahabiyyah describes the struggle of the ideology of a Wahabi who wants to escape from a total domination (herrschaft) that has eliminated the freedom and clarity of modern human thinking. This study aims to reveal the struggle of a Wahabi jihadist as reflected through internal elements of the Hikayah Wahabiyah. To uncover this ideological struggle, I use the ideological criticism approach to the intrinsic elements of the novel. Based on the analysis results are summarized, that (1) the word "jihadis" in this novel is interpreted as a kinayah which has two meanings, haqiqi and majazi (real and figurative). The meaning of haqiq $i$ is those who strive in jihad through the path of war, while the meaning of the majazi is those who strive to maintain their ideological beliefs. (2) the intrinsic
\end{abstract}


elements of literature built by the author in general illustrate the ideological struggle of a mutadayyin (follower of the Wahhabi ideology) who turns into a muntakis (someone who escapes from Wahabi ideology).

[Hikāyah Wahābiyyah telah dicekal (2013) di Saudi Arabia karena dianggap merongrong kehormatan agama, institusi, dan stabilitas negara. Hikayah wahabiyah menggambarkan pergulatan ideologi seorang wahabi yang ingin melepaskan diri dari sebuah dominasi total (herrschaft) yang telah melenyapkan kebebasan dan kejernihan berpikir manusia modern. Kajian ini bermaksud untuk mengungkap pergulatan ideologi seorang "Jihadis" Wahabi yang tercermin dalam unsur-unsur intrinsik novel Hikāyah Wahābiyyah. Untuk mengungkap pergulatan ideologi ini, saya menggunakan pendekatan kritik ideologi pada unsur-unsur intrinsik Novel. Berdasarkan hasil analisis disimpulkan bahwa (1) kata "jihadis" dalam novel ini dimaknai sebagai sebuah kināyah yang memiliki dua makna, haqiqi dan majāzi (asli dan kiasan). Makna asli yaitu orang-orang yang berjihad melalui jalur peperangan, sedangkan makna majazi yaitu orang-orang yang berjuang atau berjihad untuk mempertahankan ideologi yang diyakininya. (2) unsur-unsur intrinsik sastra yang dibangun pengarang secara umum menggambarkan tentang pergulatan ideologi seorang mutadayyin (penganut ideologi wahabi) yang berubah menjadi seorang muntakis (seseorang yang melepaskan diri dari ideologi Wahabi).]

Keywords: Hikayah Wahabiyyah; ideologi; jihadis; tadayyun; intikas

\section{Introduction}

Hikayah Wahabiyah ${ }^{1}$ is known as a novel that depicts the anxiety of a man of letters towards the issues of social, cultural, and political aspects as exist around his life. This situation that led him to feel worried about is caused by the domination of an ideology, namely wahabism. The author of this novel is a male Arab named Abdullah alMofleh who feels exceedingly disrupted by such condition. From the beginning, this work has been forbidden to spread widely in the Riyadh International Book Exhibition 2013 as it is considered to potentially destroy the prevailing way of life, as well as the social structure. ${ }^{2}$ Thus,

\footnotetext{
${ }^{1}$ Abdullah al-Mofleh, Hikāyah Wahābiyyah (Beirut: Al-Markaz al-Tsaqafi al-Arabi, 2013).

${ }^{2}$ The banned news can be accessed through www.radiosawa.com, https://www.ala raby.co.uk, and www.alsharq.net.sa/tag/rybookfair (February 18, 2016).
} 
the novel also plays a sketch illustrating the existence of ideological struggle of jihad as a sacred, high values, and jihad as an expression of rejection and disagreement. ${ }^{3}$

The novel also tells a life adventure of a wahabi proponent who feels so exhausted from holding that ideological typology. He conveys that the ideology becomes absolutely irrelevant to the current situation. This feeling has brought him to have worries and internal struggle of thought. At the end of this story, this follower made a decision to do intikas, that is to stay away from wahabism where he calls someone who holds the ideology as tadayyun. Later on, he comes to a certain belief that an ideology should not judge the life as black-and-white phenomenon. Even, his thought is prone to be considered as liberal. This is seen as a new model of fight by wahabi jihadist society. This study, therefore, aims to reveal the struggle of ideology of a wahabi proponent as depicted through those internal elements of literature.

\section{Methods}

The Hikayat Wahabiya novel is full of critics toward the ideology that prevails in Saudi Arabia. According to Budi Hardiman, kritik ideologi (the critic of ideology) is a form of self-reflection to free human knowledge if it falls to freeze in one corner of two poles, which are either transcendental or empirical. ${ }^{4}$ The method of critics of ideology has been regarded successful to highlight diverse aspects such as thought, social, cultural, as well as political, as written in many texts of literature. ${ }^{5}$

The study, then, comes to analyze any kind of ideological struggle that appears on the Hikayat Wahabi novel through investigating the intrinsic elements inserted by the author. According to Thaha Wadi, intrinsic elements that construct a novel must be event (alhadazt), figure and characters (al-syakhsiyyat), time setting (al-zaman),

\footnotetext{
${ }^{3}$ Publisher's foreword accessed February 18, 2016, http://www.neelwafurat. com/itempage. aspx?id=lbb219464-195429\&search=books.

${ }^{4}$ F. Budi Hardiman, Kritik Ideologi (Yogyakarta: Kanisius, 2009), 33.

${ }^{5}$ Muhammad Zaki al-Asymawi, Qadaya al-Naqd al-Adabi (Kairo: Dar al-Nahḍah al-

'Arabiyah, 1979), 419.
} 
place setting (al-makan), depiction of narration (al-sard al-hiwar), language (al-lughah), language style (al-uslub) and plot (al-habakah) ${ }^{6}$

Literary works with various types of genres have a very important role in producing meanings that reflect the substance of ideology. Ideology in a literary work appears in the form of codes. ${ }^{7}$ Hikayat Wahabiyah is one example of a literary work laden with ideological criticism that wants to free himself from the shackles of rules that have been binding on it. The ideological criticism used by the author through Hikayat Wahabiyah is evident in the intrinsic elements of the novel he built.

\section{Result}

\section{A Brief of Wahabism}

Wahabism is a renewal movement of thought that is based on the purification of Islam. This ideology was founded by Muhammad ibn Abdil Wahhab (1703-1978). ${ }^{8}$ This movement appears as a respon toward the ubiquity of deviation of Islamic practices called bid'ah. According to Ahmad ibn Hajiz, the term wahabism was not given by Muhammad ibn Abd al-Wahhab's followers. Instead, the term was used by his opponents or those who argue against his thoughts. The proponents of this ideology call themselves al-salafiyyun, and its proselytizing movement is called as al-dakwah al-salafiyyah. ${ }^{9}$

\footnotetext{
${ }^{6}$ Hasan Suwandi and Azadah Karem, Ru'yah ila al-Anașir al-Rawā'iyah, accessed February 18, 2016, http://cls.iranjournals.ir/article.pdf.

${ }^{7}$ Mohamed Rabeea, al-Nasaq al-Idiyuluji wa Binyah al-Khitāb al-Rawa'i li alRawaiyyaah Ahlam Mustanghami (Aljazair: Jami'ah al-Jazair, 2003/2004), 11.

${ }^{8} \mathrm{His}$ full name is Muhammad Ibn Abd. Al-Wahhab ibn Sulaiman ibn Ali ibn Muhammad ibn Ahmad ibn Rasyid al-Tamimi (1115 - 1206 H / 1701 - 1793 AD) M . He was born in the city of Najed. He grew up under the supervision of his father Abdul Wahab during the reign of Abdullah ibn Muhammad ibn Hmd ibn Mu'ammar. Muhammad Ibn Abd. Al-Wahhab was taught by his father Hambali fiqh, interpretations and hadith. He studied many books of Shaykh al-Islam Ibn Taymiyyah and Ibn al-Qayyim. Abdullah al-Shalih a-Utsaimiyyin, Al-Syaikh Muhammad Ibn Abdul Wahhab Hayatuhu wa Fikruhu (Riyadh: Darul Ulum, 1993), 23.

${ }^{9}$ Ahmad ibn Hajiz, al-Syaikh Muhammad ibn Abd. Al-Wahhab 'Aqīdatuhu alSalafiyyah wa Da'watuhu al-Islāhiyyah wa Tsanā'u al-'Ulamā 'alaih, 11 \& 28, accessed February 27, 2016, https://d1.islamhouse.com/data/ar/ih books/single/ ar ashykh muhammed ibn abdel wahab.pdf.
} 
The fundamental principles and the movement of this ideology are based on monotheism, help of the Prophet, devotional visit to a sacred place, innovation, the order of good and the prohibition of evil (amr ma'ruf nahy munkar), the judgment of infidel, war (al-qital), individual interpretation (ijtihad) and tradition (taqlid). In general, there are two fundamental principles of this ideological movement, which are, firstly, the call toward monotheism or the purification of religious practices, and secondly, the opening of individual interpretation and the rejection of tradition. ${ }^{10}$

According to Madawi Rasheed, Wahabi is an authoritarian thinking. Wahhabis believe that their understanding is the purest and most Islamist while others are considered bidah or deviate from Islam. Official Wahabiyya is religiously dogmatic, socially conservative and politically acquiescent. ${ }^{11}$ Although the Wahhabis consider themselves to be pure representations of Islam, it does not mean that the leaders or ulamas also share the same view. In Saudi history, contradictions and misleading each other have occurred between leaders or scholars of the Wahabi sect themselves. For example, the 1979 siege of the Masjid alHaram was carried out by a group led by Juhayman al-Utaybi and Muhammad bin Abdullah al-Qahtani based on dissatisfaction with the Saudi government which was considered not to apply Islam as a whole and adopt western culture, as well as criticism which was carried out by many Saudi scholars in the 90s against the kingdom which had been deemed deviated from Islamic teachings.

Some famous opposition leaders are Safar Hawali, Salman alAwdah, and 'Aidh al-Qarni. Although there are problems and disagreements in internal scholars and Wahhabis, this teaching remains solid as the official teachings of the state held by the Saudi government. Wahabi's Islamic teaching is the paradigm of governing Saudi Arabia both from the economic, educational, cultural and social aspects of

\footnotetext{
${ }^{10}$ Muhammad ibn Abdillah ibn Sulaiman al-Salman, Da'wah al-Syaikh Muhammad Ibn Abd al-Wahhab wa Atsaruha fi al-Alam al-Islami (al-Mamlakah al-Arabiyah alSu'udiyyah: Wuzarah al-Syu'un wa al-Awqaf wa al-Da'wah wa al-Irsyad, 1422 H), 27-66.

${ }^{11}$ Madawi Rasheed, Contesting the Saudi State: Islamic Voices from a New Generation (New York: Cambridge University Press, 2007), 7.
} 
society, including in foreign politics. ${ }^{12}$ Hikayah wahabiyah is one example of the Wahhabi rebellion against the ideology which is considered to have been the freedom of thought in Saudi Arabia.

The struggle of Jihadist's ideology in Hikāyah Wahābiyyah appears in the intrinsic elements of the novel that was built by the author. For this reason, in this section i will present various struggles of Jihadist's ideology that appear in the figure and personification, plot, settings, language style, and author perspective.

\section{Ideological Struggle at Figure and Personification}

If the novel is not completely read, we will find it hard to find and understand the main figure's name because the author, when telling the story, uses pronoun "I". The figure's name can be found in a story tittled "Zauq Sayyi" (bad foreboding), and "fi Isy al-Dababir (in the nest of bees). The two topics start to tell a conversation calling the 13 figure's name "I" with "Mut'ab". The term "mut'ab" literally means "tired" which is a name uncommonly used among Arabs. ${ }^{14}$ The word choice appears to reflect the ideological struggle faced by the author where that ideology frequently contradicts the reality around.

Additional figures inserted along the story are also played. Their names are Umar, Bakheit and Bandar. They serve as Mut'ab's closed friends since they were students of junior high school. Each of them was taking different path of life as described in the text. Those differences are depicted through this line:

Umar, Bakhet and Bandar, they exist and were born, living their own lives with their own way, their own views. They learn from choices they have made, and prioritize one thing above the others in deeds. They all reject all forms of domination, injustice as well as slaughter. All of them urge to sun light their country so that darkness gone. ${ }^{15}$

\footnotetext{
${ }^{12}$ Hasbi Aswar, "Politik Luar Negeri Arab Saudi dan Ajaran Salafi-Wahabi di Indonesia," Jisiera: The Journal of Islamic Studies and International Relations 1 (2016):15-30.

${ }^{13}$ Abdullah al-Mofleh, Hikayah Wahabiyah (Maroko: al-Dar al-Baidha, 2013), 85 \& 122.

${ }^{14}$ Ahmad Mukhtar Umar, Mu'jam al-Lughah al-Arabiyyah al-Mu'ashiroh (Kairo: 'Alam al-Kutub, 2008), 293.

${ }^{15}$ Abdullah al-Mofleh, Hikayat Wahabiyah, 442.
} 
Bakheit is the first additional figure told in a part titled Marqas al-Syeikh Bakheit, which means Syeikh Bakheit's discotheque. ${ }^{16}$ The titling appears to be an irony the author urges to deliver about this figure. Bakheit was once a pious man (mutadayyin). He was absolutely obedient to the religious doctrine he believes in. But, he turns around one hundred and eighty degrees to become a crazy man of material world. ${ }^{17}$

The title given shows a serious irony in accordance with the shifting ideology of a wahabi proponent who cannot resist to hold the doctrine in which believed since young age. Along the story, Bakheit was told to face three different phases of ideological struggle. Those are the phase of mutadayyin, the phase of rebellion, and the last past, which is an ideological aware as a normal type hold by the majority that reflect modesty, not excessive in life.

Bandar, on the other hand, becomes the second additional figure where his life story was also told in the novel. In contradistinction to Bakheit, Bandar made up his mind to become a jihadist. This decision was made after his aunty was murdered by the soldiers of Iraq when the war between Iraq and Kuwait took place. A deep sorrow was covering his heart, mixed with an unlimited happiness as he feels to be capable of doing jihad in the way of Allah against America in the near future. ${ }^{18}$

Through Bandar's life story, the ideological struggle is also depicted into three phases. His first phase is pra-religious state. The second is the tadayyun phase shown by his association with jihad movement. And, the last phase is to be a normal one holding a common view in ideology as a sign of his self-awareness. Umar, furthermore, become the third additional topic along the story. Umar is depicted as a man who consistently holds wahabism as a way of life until the death finds him. Umar, then, is seen as a true "jihadist". Among his battle fields are Palestine, Bosnia, Chechnya, Afghanistan, and Iraq. ${ }^{19}$

The long debates between the figure "I" in this novel in conjunction with Umar on al-Qaeda, war, terrorism, the fight of

\footnotetext{
${ }^{16}$ Ibid., 7.

${ }^{17}$ Ibid., 7-17.

${ }^{18}$ Ibid., 35.

${ }^{19}$ Ibid., 53.
} 
jihadists, as well as his unshakable belief shows that Umar is a true jihadist and mutadayyin. By the end of his life, Umar was known as a Muslim martyr, a syahid. The story of their lives becomes the reality that exists around Mut'ab's life, the prime figure in this novel. That kind of reality leads Mut'ab to face an ideological struggle that stays long. At the end, he concludes that everyone can choose their own way of life that no one can forces and intervenes their choices. As a wahabi follower, Mut'ab, however, should accept that hard reality. In addition to the main characters and assistants, in Hikayat Wahabiyah there are also some background figures. These figures, although only discussed a little but still contribute to the struggle of the mainstream ideology. Among the background figures mentioned in wahabiyah hikayah are Abid and Captain fawwaz.

Abid returned from visiting al-Ikhwah ${ }^{20}$, he turned into a Mutadayyin. Jama'ah Tabligh is well known for his teachings, which is out of the house in order to preach. The Da'wah Method of the Tablighi Jama'at influenced many young people who were thirsty for religious knowledge and religious atmosphere. Mut'ab liked Abid besides being a follower of the Tablig Jama'ah, Abid also had similarities with Mut'ab, namely both suffering from "Ta'ta'ah". ${ }^{21}$ The difference between Ta'ta'ah which was experienced by Mut'ab was stuttering while Abid slurred. Abid is a companion of Umar who later along with him becomes a Jihadist.

Captain Fawwaz is a Badawi (Saudi Arabia) and a respected soldier in the passport management division. He was accused of being part of the al-Qaeda network. ${ }^{22}$ An accusation that is far from the truth. The youth fighters (al-Jihadi) understood very well that captain Fawwaz strongly rejected the jihad operation being transferred to Arab countries. As a soldier who was sworn in by the State he argued that anyone who carried out acts of sabotage and murder in his own country was categorized as ignorant and infidels (takfiriyyin). Official government regulations that have been understood implicitly and explicitly. ${ }^{23}$ Captain Fawwaz is a salafi believer (wahabi). ${ }^{24}$. Mut'ab

\footnotetext{
${ }^{20}$ The name of Jama'ah Tabligh community

${ }^{21}$ Ibid., 47-50

${ }^{22}$ Ibid., 74

${ }^{23}$ Ibid., 76
}

Copyright (c) 2019 by Karsa. All Right Reserved DOI: 10.19105/karsa.v27i1.2271 
calls it Jihadi (Wahhabi warrior), though he is very obedient to the government. He was accused of al-Qaeda network members, for helping the City and entering Iraq through Syria. ${ }^{25}$

The story of Captain Fawwaz reveals the submissive Saudi government of the United States, so that the people who are supposed to be protected become targets of libel for the sake of America. This story contributes to Mut'ab's disappointment over Wahabi's teachings which are the laws of his country.

\section{Ideological Conflict on The Plot}

Events told along the novel's story are disordered. Generally speaking, it is hard to affirm the clear and easily understandable plot. Nevertheless, the plot is believed to show the picture of ideological struggle of I when he faces the reality which is full of dilemma, coming without any permission. The plot seems to be written in back-and-forth style, and gives an impression of its messed writing style. Through this kind of writing style, we can draw a conclusion that it becomes a symbol of worries and anxieties, as well as the ideological struggle in coping with the problems arouse. In general, the plot is flat since the beginning till the end without any anti-climax. In the study of literature, this kind of plot is called plural plot, which is a plot providing several primary stories. The plot of this Hikayat Wahabiyah novel can be summarized as follow.

The beginning of the story shows the reality existing around the figure I as well as the I's attitudes toward that kind of reality. When Bakheit's life story accommodates a secular type of life style, Umar and Bandar take their paths of life to become jihadists. The story was begun by telling the reality of Saudi Arabia which has been never expected by the non-Arabs. This telling appears on a title of Marqash al-Syeikh Bakheith:

You feel like entering a cave. The sparkling light of night clubs forces you to close your eyes with your hands. Not to be surprised, a small discotheque in a two star hotel contains two

\footnotetext{
${ }^{24}$ Ibid., 82

${ }^{25}$ Ibid., 84
} 
females of northern Africans dancing on the stage following the music bits.... ${ }^{26}$

The middle part of the story tells us on the I's life as a primary figure when he was in childhood and teenage, including those who have influences onto his mind and ideology. The title of al-Shahwah, alTsaqb al-Aswad (the resurgence, the black hole) told this phase of his life.

Since I was a child, I love the mutadayyin people whom they usually call al-muthawi'ah. The term was a tradition used during al-katatib era, namely where a public place used for learning. In there, the children learn al-Qur'an and Hadith from teachers who have beard. They were called al-muthawwi (the obedient one). ${ }^{27}$

The end of story gives us different life paths which were taken by these three figure assistants. Bakheit releases his secular type of life style, and a far tendency of religion. On the other hand, Bandar turns back to his family after a short period of becoming a jihadist, where he finally become a martyr. What about the figure I? Mut'ab did feel so exhausted of the reality appearing on him, and contradicting his mind and ideology.

I never meant to write notes on Umar, Bakheit, Bandar and the others. However, I do ever feel that my life is void and useless. On the other hand, I do know more, and their rights, and other human beings to know, and read again more closely not through the language of media, but through the common language of people, more precious. When I started to write, I do not know them, because, actually, I tell my own life. On how I feel revolted everyday for six months, and how I did feel hurt of oppression, sorrow and other hurts. How I sink more deeply as a muntakis, and also how I shift the tadayyun with something bad

\footnotetext{
${ }^{26}$ Ibid., 7

${ }^{27}$ Ibid., 150
}

Copyright (c) 2019 by Karsa. All Right Reserved DOI: 10.19105/karsa.v27i1.2271 
and scary, which I do not know its essence. So, how can I become a hypocrite, liar, pretender and acting blasphemy .. ${ }^{28}$

By the end of the story, the I was given a verdict of prison for ten years where three years later he died inside. The story ending is absurd. The author seemingly urges to convey that this novel contains things which have been disliked by the Saudi Arabia government because some figures are real. This is told in his word of dedication:

If there is an event of name in this novel resembling the ones exist, that, in fact, is a intentional act, and the only thing that deserves of blame is the reality itself. ${ }^{29}$

In fact, this book becomes one of works banned by the Saudi Arabia government. The jail and the death of I at the end of the story serve a symbol of different ideologies which are to be chained in Saudi Arabia and the death of freedom of thought as all kind of thought must orient toward wahabism. The death of I becomes a symbol of awareness that this kind ideology is in fact dead already and deviates. He compares his own ideological adventure using the term " $a$ stutter wahabi". 30

I am the one who is meaningless with this fragile faith and piety, how come they put their lives on me .. wahhabism, humanity, truth, less or more, I do not care. The only thing I do is that everything deserves to tell. ${ }^{31}$

Seen through its pattern, the plot consists of disappointment toward the ideology, the struggle of ideology, and the plot of ideological decision. Nevertheless, that becomes the end of I's story in the novel according to the plot perspective.

\section{Discussion}

\section{The Critic of Ideology in Settings}

The settings employed along this novel either time, place, culture or characters are strongly related to the critics and struggle of

\footnotetext{
${ }^{28}$ Ibid., 443

${ }^{29}$ Ibid., 5

${ }^{30}$ Ibid., 444

${ }^{31}$ Ibid., 444
} 
ideology of I figure. In general, the time setting of this novel is divided into three parts. They are, firstly, childhood and teenage as the phase of ideological construction. The second part is maturity where the figure faces a phase of struggle of ideology. The last past is final phase where this ends the struggling process.

The I figure was constructed ideologically since he was in childhood and in a mature age. These phases appears on a title of alShahwah al-Tsaqb al-Aswad. This sentence means a raise of religious movement - that is Saudi Arabia - is a black hole ${ }^{32}$.

Al-Shahwah al-Islamiyah comes and forms my life for the first time, especially when it comes to tadayyun (wahabism). I do love the mutadayyin (pious Wahabi proponents) since I was a child. ${ }^{33}$

The I's childhood was strongly influenced by a man who makes an Islamic call to prayer (azan), as well as a tutor who teach the reading of Qur'an. The I calls him Syeikh al-Najdi, that means a teacher from Najed, as he proclaims:

"It is true that I proceed tadayyun before I know him (Syeikh alNajdi). However, I haven't committed the real and true tadayyun, but after I know him. ${ }^{34}$

The second time setting of the I figure is the maturity phase. Inside, the struggle of ideology was shown clearly through dialogues of the I with the assisting figures. The reality that shows up, and that contradicts a believed set of tadayyun values leads him to face a long phase of ideological struggle. There are two types of reality in this phase. First, the secular life pattern which is free of religious values depicts the reality of Saudi Arabia people's life style currently that is not in line with wahhabism as countries' ideology. This phenomenon was shown through the story of Syaikh Bakheit's discotheque.

\footnotetext{
${ }^{32}$ The term al-Shahwah is also used as al-Shahwah al-Su'udiyyah or Shahwal Bilad alHaramain. It is a raise of religious movement in Saudia Arabia in eight century. This movement was initiated by Salman al-Audah, 'Aid al-Qarni, Safar al-Hawali, and Nasher al-Amr. At the moment, this al-Shahwah movement faces resistance from liberal movement that judges al-Shahwah as an ideology teaching radicalism.

${ }^{33}$ Ibid., 151

${ }^{34}$ Ibid., 154
}

Copyright (c) 2019 by Karsa. All Right Reserved DOI: 10.19105/karsa.v27i1.2271 
"The true reality at the moment is that the boundary is already destroyed. The color mixs. The limitation of content and boundary becomes blurry. And, we are the generation of alshahwah that changes already. We resemble children of broken home whom no one takes care. The mother can only hope if the father can take cares everything. ${ }^{35}$

At this phase, a lot of changes take place. Ideologically, he turns from a mutadayyin to become a muntakis for his new life style. This appears on a title of al-muntakis.

The second primary reality is the jihadist community. This becomes the part that fills most the novel's content. The long dialogue between the I and other jihadists shows a complex phenomenon of ideological struggle leading to either pro or contra response.

- We agree that al-Qaeda is a truly existing organization on earth. We do also agree that the organization's purpose is to extinct the tyrannical tendency on Muslim society especially Palestinians, Afghans, and ...

- Including Bosnia and Chechnya ..

- Yes, indeed, Bosnia and Chechnya.

- Allow me to ask: Do you think that killing American people would extinct that tyranny toward the people of Palestine, Afghanistan, Bosnia and Cechnya?

- It is true that qisas can help make justice come true because the American civil is under the colonizing countries' protection. Hence, when those countries kill Muslim societies, we have to revenge by killing their people. ${ }^{36}$

The phase of maturity or the final ideological struggle usually appears through the I's last statement:

For me, I do love the people who fight for Islam and its community, especially those who are engaged in war (mujahid) in the way of Allah with their body and soul. They are far from the complexity of discourse on the classification of this

\footnotetext{
${ }^{35}$ Ibid., 18

${ }^{36}$ Ibid., 131.
} 
movement, either etymologically or categorization-based. They are high far above all forms of tricks, conflicts, polarizations .. for me, they are like legendary heroes forever. ${ }^{37}$

The statements and attitudes shown by the I figure depict a phase of maturity of thinking, and become the end of his ideological struggle. The ultimate phase of I's maturity is his total acceptance toward all kind of differences around him as a reality that the implementation of jihad fi sabilillah has many paths more than ever imagined.

\section{The Critic of Ideology Through Language Style}

The Hikayat Wahabiyah written by Abdullah al-Mofleh has a unique of language style utilization. The language style is not separated from the principles of ideology, ideological struggle and the critics of ideology aimed to show for the readers. Thus, that kind of style becomes the novel's special character.

1) Joining the types of monologue and dialogue

The first special character of the novel appears through the technique of storytelling that combines monologue and dialogue. This style is highly interesting to show because it is related to the technique of writing in delivering ideas and thoughts to the readers. The monologue type of story delivery is in general used by the author to send new thoughts and ideas. The al-muntakis title, for example, is delivered through monologue technique by the I figure. The author urges to give a picture and understanding on the meaning of almuntakis according to his own perspective. The monologue, for instance, is as follow:

The world of al-muntakis is a world full of question. It is like a virus that tries to protect its own self. On the other side, it is also like the antivirus that provides the answer. The world of almuntakis and its actors are two different things, resembling a victim waiting for a death penalty ... so on. ${ }^{38}$

\footnotetext{
${ }^{37}$ Ibid., 226.

${ }^{38}$ Ibid., 18-19.
}

Copyright (c) 2019 by Karsa. All Right Reserved DOI: 10.19105/karsa.v27i1.2271 
The author, through this title, aims to show the meaning of almuntakis in his own understanding, as well as its relation to his thoughts and ideology. For that, he poses any questions for himself where, subsequently, he himself answers those questions with explanations. When we read this part, we are like not reading a novel, but a philosophical book.

With regard to the storytelling of dialogue, the technique is usually employed by the author to counter any thought coming from outside which is not compatible with his. This technique appears through titles taken from the figure names. Those names are actually representations of ideological symbols or forms of thought urged to deliver, either ones come to an agreement or ones refuted. There are several titles using names which using dialogue mode in sending the messages of ideas and thoughts. Those are Syaikh Bakheit Discotheque, Bandar, Umar, Fawwaz and Romi al-Ahmar. In addition, the are several titles that use other names for its labels, but using dialogue technique, such as kifahan fi Muwajahah al-Qaidah which means a fight to face al-Qaeda. An example for a part title Umar:

After being silent for a minute, I start to ask him:

- How are the Ikhwah (brothers) in the battle field?

- Praise be to Allah that they are good.

- Where are you now Umar? In Iraq or Chechnya? the tast time, I heard your are in Chechnya? .. ${ }^{39}$

The story delivery with dialogue generally is with regard to ideologies of Jihad as appear on the dialogue above.

\section{2) Symbolic Word}

Symbolic style of language use also appears strikingly at names and places. For example, the the name of primary figure presents a symbol of self-independency from a jailing ideology, that is wahhabism. However, the independency also implies balance and moderate stance toward the reality.

I started to feel that I'm amidst the apostates... ${ }^{40}$

\footnotetext{
${ }^{39}$ Ibid., 53-54

${ }^{40}$ Ibid., 25
} 
Liberating from tadayyun means that you leave the identity you have been held for years with, and dedicated for... ${ }^{41}$

I also pretend like I do not see him surprised to see me without beard for the first time... ${ }^{42}$

The word Mut'ab itself is the symbol of being tired in conjunction with the ideological struggle when the figure feel exhausted by being a mutadayyin, and then, decide to be a muntakis. It's an irony.

The ironic style of language use at this novel appears in a part titled Syaikh Bakheit's Discotheque. The word syaikh versus discotheque becomes an irony when the word syaikh which is actually associated with high values is compared to discotheque (marqsas). Consequently, the word now becomes meaningless from a pious one to be a dishonored one.

The two contradictive words also become another irony. Syaikh is used to present a personification of a mutadayyin, which subsequently shifts to set his previous ideology free for some reasons. The shifting attitude as to be a muntakis who has a liberal tendency presents the irony.

Another irony will be the discotheque in contradistinction to wahhabism. The story of Syaikh Bakheit's discotheque becomes the first title told by the author. Certainly, this title teases sharply toward the Saudi Arabia government that makes wahhabism as a state ideology. The title presents an irony regarding the reality in the country when it declares Islam as its ideology. It is called al-shahwah, where the declaration was stated to support the raise of Islam by turning back to its pure teachings.

\section{The Perspective of Ideological Critic}

From the personality perspective, the type of personification centers on the I figure, and therefore, it is called I-ness perspective. Through this kind of perspective, the author as if tells everything about himself, including experience, view, belief, and so on. ${ }^{43}$ Hence, the

\footnotetext{
${ }^{41}$ Ibid., 22-23

${ }^{42}$ Ibid., 52

${ }^{43}$ Albertine Minderop, Metode Karakterisasi Telaah Fiksi (Jakarta: Yayasan Obor Indonesia, 2005), 106-107.
} 
point of views is made as a medium of critics, and of sight toward the ideological struggle of I.

The main perspective has a strong relation to the concept of tadayyun. According to the I figure, tadayyun merely presents pseudo reality. For that, there are three things disturbing the I concerning tadayyun:

1) That tadayyun makes someone view the life around with enmity perspective. In the other words, a wahabi proponent sees the others as his enemy.

2) That tadayyun make the life itself full of enmity. In the other word, those who are non-wahabi followers are enemies.

3) That the circumstance is fundamentally based on full of enmities where tadayyun reveals all forms of those enmities.

That is to be the I's worries as the authors' representation with regard to wahhabism that has been long a hostile for the other, as well as see the non-wahabi proponents as hostile. It indicates that there must be something wrong with tadayyun. There must an ideological rebellion. It is a must for all mutadayyin to leave it. ${ }^{44}$

The critics of ideology as related to jihad and terrorism become another one. This topic raises an ideological struggle that lingers very long. The following will present some debates that show the existence of ideological struggle around the meaning of jihad and terrorism between the I and Umar al-Jihadi:

- Come on, tell me what are the main point of differences which is true and serious

- The first difference is the definition of al-Qaeda as a terrorism organization. You are now at that position. So let me use this definition which is actually propagated by the media of America, Zionism, Iran, and the Arab, the traitor?

- So, what al-Qaeda is doing at the moment is not a terror? So what is terrorism?

- Terrorism is what "Israel" and America have been doing. I do understand that you are incapable of understanding such definition more deeply. Said Umar more convincingly.. ${ }^{45}$

\footnotetext{
${ }^{44}$ Abdullah al-Mofleh, Hikayat Wahabiyah, 91.

${ }^{45}$ Ibid., 128-129.
} 
From the text above, The ideological struggle was seen very clearly around the meaning of jihad and terrorism. Based on the dialogue, the I basically urges to liberate wahhabism that makes jihad in a sense of war as a true fight. He saw that there is a meaning shifting from the true jihad that becomes terrorism as performed by the alQaeda. This kind of struggle shows a disagreement toward terrorism which uses jihad label.

\section{Conclusion}

In general, Hikayah Wahabiyah tells the fight story of Jihadist community in defending their own idealism and belief. The jihadists mentioned in the novel present kinayah which has to meanings: real and figurative. The real meaning is meant to those who perform jihad through wars as depicted by some assisting figures. The figurative meaning is referred to those who fight to defend the ideology in which believed to be different from the previous ideology. Theoretically, the critics of ideology of the novel is a form of opposition toward a delusion being a barrier of human social practices to bring goodness, truth, happiness and freedom into reality according to the author's perspective.

Hikayah Wahabiyah attempts to depict a picture of ideological struggle by a mutadayyin who, then, turns to be a muntakis. Along the struggling process, the author, by using self-criticism method, poses critics toward wahhabism that has been long time the ideology of Saudi Arabia.

\section{Bibliography}

'Ayyash, Uhaimidah. Tajalliyat al-Dalalah al-Idiyulujiyyah fi alRiwayah wa 'Unf al-Fadha'. Al-Jazair: Majallah al-Makhbar, Universitas al-Baskara, 2013.

al-'Alim, Mahmud Amin. Al-Tsaqafah wa al-Tsaurah. Kairo: Al-Hayah al-'Ammah li Qushur al-Tsaqafah, 2010.

al-'Ammuri, Al-Sa'id. Al-Kitabah wa al-Tasykil al-Idiyulujiya fi alRiwāyah al-'Arabiyyah al-Mu'ashirah. Aljazair: Universitas alHaj el-Khedhr, 2013.

al-Asymawi, Muhammad Zaki. Qadhaya al-Naqd al-Adabi. Kairo: Dar al-Nahdhah al-'Arabiyah, 1979. 
al-Audah, Salman. As-ilah al-Tsaurah. Beirut: Markaz Nama, 2012.

al-Dakhil, Turki. Salman al-'Audah; Min al-Sijn ila al-Tanwir. Beirut: Madarik, 2011.

al-Fasi, 'Ilal. al-Naqd al-Dzati. Kairo: al-Mathba'ah al-'Alamiyah, 1952.

al-Hasyimi, Ahmad. Jawahir al-Balaghah fi al-Ma'ani, al-Bayan, wa al-Badi'. Indonesia: Maktabah Dar Ihya al-Kutub al-Arabiyyah, 1960.

al-Hasyimi, Muhammad 'Adil. Fi al-Adab al-Islami; Tajarib wa Mawaqif. Damaskus Beirut: Dar al-Qalam - Dar al-Manarah juz $1,1987$.

Al-Mofleh, Abdullah. Hikayat Wahabiyah. Beirut: Al-Markaz alTsaqafi al-'Arabi, 2013.

al-Salman, Muhammad ibn Abdillah ibn Sulaiman. Da'wah al-Syaikh Muhammad Ibn Abd al-Wahhab wa Atsaruha fi al-Alam alIslami. Arab Saudi: Wuzarah al-Syu'un wa al-Awqaf wa alDa'wah wa al-Irsyad, $1422 \mathrm{H}$.

al-Syi'wairy, Muhammad Sa'd. Taṣhih Khața Tarikhi Hawla alWahhabiyyah. al-Mamlakah al-Arabiyyah al-Su'udiyyah: alJami' ah al-Islamiyyah, $1319 \mathrm{H}$.

al-Wahab, Muhammad Ibn Abd. Kitab al-Kaba'ir. Kairo: Maktabah Ibnu Taimiyyah, 2010.

Aswar, Hasbi. "Politik Luar Negeri Arab Saudi dan Ajaran SalafiWahabi di Indonesia." Jisiera: The Journal of Islamic Studies and International Relations 1 (2016): 15-30.

Ayyub, Muhammad. al-Syakhshiyyah fi al-Riwayat al-Filasthiniiyah alMu'ashirah. 1996.

Dellinger, Susan E. Al-Tawashul Ragm Ikhtilafatina. Riyadh: Maktabah Jabir, 2015.

Eco, Umberto. Al-Simiyaiyyah wa Falsafah al-Lughah, trans.: Ahmad al-Sham'i, cet. 1, Beirut: Al-Munazhzhamah al-'Arabiyyah li alTarjamah, 2015.

Endaswara, Suwardi. Metode Penelitian Sastra. Yogyakarta: Pustaka Widyatama, 2004.

Esten, Mursal. Kesusastraan: Pengantar Teori \& Sejarah. Bandung: Angkasa, 2000. 
Fadhel, Shalah. Ilm al-Uslub; Mabadiuh wa Ijraatuh. Kairo: Muassasah al-Mukhtar, 1992.

Fadhel, Shalah. Manahij al-Naqd al-Mu'ashir wa Mushthalahatuh. Kairo: Merit, 2002.

Hall, Edward T. al-Lughah al-Shamitah (The Silent Language). trans.: Lamis Fuad al-Yahya. Amman, 2007.

Hamid, Sha'ib Abdul. al-Wahabiyyah fi Shuratiha al-Haqiqiyyah. Beirut: al-Ghadir, $1415 \mathrm{H}$.

Hardiman, F. Budi. Kritik Ideologi. Yogyakarta: Kanisius, 2009.

Hasan, Anis Zaky. Fyodor Dostoyevsky al-Insan al-Sharshar aw rasa'il min a'maaq al-Ard. Beirut: Dar al-Ilm al-Malayin, 1959.

Marini, Eko. Analisis Stilistika Novel Laskar Pelangi Karya Andrea Hirata. Surakarta: Pasca Sarjana Universitas Sebelas Maret, 2010.

Minderop, Albertine. Metode Karakterisasi Telaah Fiksi. Jakarta: Yayasan Obor Indonesia, 2005.

Reboul, Ann. and Jaque Moeschlher. Al-Tadawuliyah al-Yaum; 'Ilm Jadid fi al-Tawashul. trans: Muhammad al-Syaibani, alMunazhzhamah al-'Arabiyyah li al-Tarjamah, 2003.

Habasy, Iskandar. Hikayah al-Hikayat; Qira-at fi Riwayat Muashirah. Beirut: Dar al-Adab, 2009.

al-Alwani, Thaha Jabir. Adab al-Ikhtilaf di al-Islam. Herndon Virginia: Al-Mahad al-Alami li al-Fikr al-Islami, 1981

Keraf, Gorys. Diksi dan Gaya Bahasa. Jakarta: Gramedia Pustaka Utama, 2002.

Lecercle, Jean Jaques. 'Unf al-Lughah. trans. Muhammad Badawi. Beirut: Al-Dar al-'Arabiyyah li al-'Ulum - Al-Markaz alTsaqafi al-'Arabi, 2005.

Mandur, Muhammad, Al-Naqd al-Manhaji 'inda al-'Arab wa Manhaj al-Bahts fi al-Adab wa al-Lughah. Kairo: Nahdhah Mishr, 1996.

Mandur, Muhammad. Al-Naqd al-Manhaji inda al-'Arab wa Manhaj al-Bahts fi al-Adab wa al-Lughah. Kairo: Nahdhah Mishr, 1996.

Minderop, Albertine. Metode Karakterisasi Telaah Fiksi. Jakarta: Yayasan Obor Indonesia, 2005.

Nasution, Harun. Islam Ditinjau dari Berbagai Aspeknya jilid 2. Jakarta: UI-Press, 1985.

Nurgiyantoro, Burhan. Teori Pengkajian Fiksi. Yogyakarta: UGM Press, 2010. 
Fadhel, Shalah. Manahij al-Naqd al-Mu'ashir wa Mushthalahatuh. Kairo: Merit, 2002.

Susanto, Dwi. Kamus Istilah Sastra. Yogyakarta: Pustaka Pelajar, 2015 Tim Penyusun. Ensiklopedi Sastra Indonesia. Bandung: Titian Ilmu, 2009.

Umar, Ahmad Mukhtar. Mu’jam al-Lughah al-Arabiyyah alMu'ashiroh. Kairo: 'Alam al-Kutub, 2008.

Ya'qub, Emil Badi'. Fiqh al-Lughah al-Arabiyah wa khashaishuha. Beirut: Dar al-tsaqafah al-Islamiyyah, 1998.

Colquhoun, Alan. Criticism And Self-Criticism in German Modernism AA Files, No. 28 (Autumn), 1994.

Haryanti, Pitri, Analisis Unsur Intrinsik Novel Hachiko Monogatari Karya Kaneto Shindo. Acecssed August 15, 2016. http://jurnal.unikom.ac.id/_s/data/jurnal/v10-01/10-miu-10-01pitri.pdf/

Kusmarwanti. Alur dalam Fiksi, Bahan Mata Kuliah Kajian Fiksi, August 18, 2012.

Mangasing, Mansur. "Muhammad Ibn 'Abd Al-Wahhâb dan Gerakan Wahabi." Hunafa: Jurnal Studia Islamika 5, no.3 (2008).

Rasheed, Madawi. Contesting the Saudi State: Islamic Voices from a New Generation. New York: Cambridge University Press, 2007.

Roberts, Tyler. "Rhetorics of Ideology and Criticism in the Study of Religion." The Journal of Religion 85, 3 (July 2005).

Suwandi, Hasan. And Azadah Karem. Ru'yah ila al-Anashir alRawa'iyah. Accessed October 15, 2016. http://cls.iranjournals. ir/article.pdf.

Masyithah, Siti. Taghayyur al-Ma'na (Min Mabahits ilm al-Dilalah). Accessed October 16, 2016. http://download.portalgaruda. org/article.

al-Utsaimiyyin, Abdullah al-Shalih. Al-Syaikh Muhammad Ibn Abdul Wahhab Hayatuhu wa Fikruhu. Riyadh: Darul Ulum, 1993 